\title{
THE BENEFIT OF UTILIZING BRAIN-BASED LEARNING IN HIGHER EDUCATION ONLINE ENVIRONMENTS
}

\author{
Renee M. Winter, Grand Canyon University
}

\begin{abstract}
Higher education has experienced a significant transformation from traditional face-to-face instruction to online instruction. The purpose of this quantitative causal-comparative study was to determine to what extent postsecondary online faculty utilized brain-based learning techniques as part of their academic practices in the online asynchronous learning environment and to assess differences in the use of these techniques between online full-time and online adjunct faculty employed by two public universities and one private university located in the Southwest region of the United States. The theoretical framework of Hart's (1983) brain-based learning theory (BBLT) informed this study. The sample consisted of 539 accepted and completed surveys. The participants completed 55 questions based on brain-based learning. Quantitative data were collected using Klinek's (2009) questionnaire about brain-based learning knowledge, beliefs, and practices. The data from the questionnaire measured the online faculty's knowledge, beliefs, and practices of brain-based learning techniques. The data were analyzed using descriptive information about the sample computing frequencies of the variables. Cronbach's alpha reliabilities were conducted to complete the descriptive statistics for the first research question. The statistical analysis used for research question two and three was Multivariate Analysis of Variance (MANOVA) using a $2 \times 2$ factorial design to test the hypotheses. The researcher found that there was a significant difference between the BBLT practices of the online faculty from public $(M=3.45)$ and private universities $(M=3.28), F(1,294)=1.62$, $p=.004, \eta 2=.044$. The study revealed that there is a lack of knowledge about BBLT supporting the need for professional development and training.

Keywords: brain-based learning, online instruction, asynchronous, higher education, full-time faculty, adjunct faculty

\section{INTRODUCTION}

Higher education has experienced a significant transformation from face-to-face instruction to online instruction. The academic practices of online faculty are essential for providing meaningful learning for students and for developing students' personal, professional, and academic skills. Online faculty are a critical entity in the online learning experience. It is important to provide meaningful learning using effective instructional practices to ensure student engagement. According to Sloan

(2014), 74\% of leaders in higher education have expressed concerns that the quality of online instruction is not equal or comparable to that of courses delivered face-to-face. One way to improve the quality of instruction in the online learning environment is to examine the academic practices used to engage online learners.

Faculty are an integral part of students' online learning experiences because they aid students, maintain course content, and support completion of degree programs. It is critical for university leaders
\end{abstract}


and online faculty to understand the significance of providing meaningful learning to students by using effective academic instruction and encouraging high levels of student engagement. According to Kanter (2013), the United States has established some of the most revered institutions of higher education; however, many fall short in supporting students as they work to complete their degrees and obtain the skills needed to succeed in their future professions. Colleges and universities can provide training and professional development for online faculty that emphasizes best practices in asynchronous learning environments. Asynchronous learning environments enable students to obtain a degree while strengthening their academic skills and enhancing the skills they need for future professional experiences. More specifically, online learning enables students to develop analytical thinking skills for the workplace (Raj, 2011).

To promote quality online asynchronous instruction, it is necessary to ensure that online faculty members are highly qualified and they utilize best academic practices in the online learning environment. Freeman and Wash (2013) found that a lack of interaction with students, degradation of students, and lack of availability to students were unfavorable habits of online faculty members. Students should receive support, feedback, and guidance from online faculty in order to learn the content and build the skills they need for future professions. The capabilities and knowledge of an instructor are critical to the quality of online courses and programs (Abel, 2005; Roman, Kelsey, \& Lin, 2010; Varvel, 2007). Learners who experience a positive environment are likely to have their learning, memory, and selfesteem improved (Jensen, 2008). It is important for educators to provide a safe and comfortable environment to help build students' confidence, so they can take control of their learning.

For faculty, online academic practices should meet the diverse needs of all students, despite the challenges presented within the curriculum or course design (Braidic, 2009). Some of the factors that may affect online faculty in their use of best academic practices include job satisfaction, motivation, administrative support, salary, workload, the challenges of using the learning management system, and professional development opportunities (Gautreau, 2011). Another issue is that many online faculty members lack an understanding of their organization's culture and the demands of their institution, resulting in ineffective facilitation in the online learning environment. Online educators must understand the importance of learning styles to meet the individual student's needs (Braidic, 2009).

Brain-based learning techniques utilized by online faculty may improve asynchronous instruction by implementing carefully designed principles that consider impact before, during, and after each lesson (Akyurek \& Afacan, 2013). Examples of brain-based learning techniques include stimulating the students through engaging activities and collaborative learning groups, providing a safe environment to share thoughts and ideas, reducing anxiety and threats, offering flexibility, making resources available, and providing feedback in a timely manner. According to Jensen (2008), brain-based education is best understood as the engagement of these techniques to enhance meaningful learning for students. Brainbased strategies need to vary to accommodate students' individuality and strengths (Burton, 2009). The learning sequences related to a concept should remain logical and relate previous knowledge through an emotionally charged curriculum (Burton, 2009). A brain-based classroom should build safe environments, recognize and honor diversity, and provide organization, assessment, instructional strategies, new models, and numerous curriculum approaches (Braidic, 2009; Gregory \& Chapman, 2002). Online faculty should engage in professional development that provides training in researched academic practices that will enhance the course content and help students build new learning skills (Berg \& Haung, 2004; Mundy, Kupczynski, Ellis, $\&$ Salgado, 2011). Jensen (2011) stated that "nature's biological imperative is simple: no intelligence or ability will unfold until, or unless, it is given the appropriate model environment" (p. 6). Online faculty who utilize brain-based learning techniques have the opportunity to improve academic practices in the online learning environment. According to Braidic (2009), online faculty should provide a safe, comfortable, flexible, interactive, and supportive asynchronous learning environment 
while promoting meaningful learning that engages students through diverse academic practices.

According to Akyurek and Afacan's (2013) study, a brain-based learning approach can have an effect on a student's motivation and attitude in a classroom. Improving the quality of instruction through meaningful learning and the limited use of traditional instruction, including practices such as lectures and worksheets, allows for brain stimulation and enhanced student learning. Brain-based learning techniques aim to provide meaningful learning skills to students and to enhance academic practices for teachers (Ozden \& Gultekin, 2008). Brain-based learning supports the notion that learning is more evident in real-life experiences or scenarios related to life experiences. This holistic approach focuses on the individual's health and well-being related to learning, experiences, and the retention of content. The brain searches for meaning and seeks the ways in which concepts relate to individual experiences.

Overall, colleges and universities that support the growth of online faculty by promoting best academic practices and student engagement will providea more versatile, engaging, and active online asynchronous environment for student learning, which occurs when students are participating in the learning activities (Braidic, 2009). Sullivan and Rosin (2008) found that students engaged in active learning when the information was related to real-life experiences. Professional development focusing on brain-based learning techniques should be provided to all online faculty members to promote meaningful active learning for students in asynchronous postsecondary environments.

\section{PURPOSE}

The purpose of this quantitative causalcomparative study was to determine to what extent postsecondary online faculty utilized brain-based learning techniques as part of their academic practices in the online learning environment and to assess the differences in the use of these techniques between online full-time faculty and online adjunct faculty employed by two public universities and one private university located in the Southwest region of the United States.

\section{RESEARCH QUESTIONS AND HYPOTHESES:}

The first research question framed the research and helped accomplish the first goal of this study:
R1: To what extent do online faculty members utilize brain-based learning as an academic practice in an online asynchronous higher education environment?

As this first goal of the study was descriptive, no statistical tests were necessary, and no hypotheses were needed.

The researcher stated two additional research questions needed to accomplish the second goal of this study:

R2: Is there a difference in the usage of brain-based learning techniques as an academic practice in the online asynchronous higher education environment attributable to faculty's hiring status (full time versus adjunct)?

H20: There is no statistically significant difference in the usage of brain-based learning techniques as an academic practice in the online asynchronous higher education environment that can be attributed to faculty's hiring status (full time versus adjunct).

H2a: There is a statistically significant difference in the usage of brain-based learning techniques as an academic practice in the online asynchronous higher education environment due to faculty's hiring status (full time versus adjunct).

R3: Is there a difference in the usage of brain-based learning techniques as an academic practice in an online asynchronous higher education environment that can be attributed to the type of institution (public university versus private university)?

H30: There is no statistically significant difference in the usage of brain-based learning techniques as an academic practice in the online asynchronous higher education environment that can be attributed to the type of institution (public university versus private university).

H3a: There is a statistically significant difference in the usage of brain-based learning techniques as an academic practice in the online asynchronous higher education environment that can be attributed to the type of institution (public university versus private university).

\section{METHOD}

\section{Sample}

The population of interest in this study was 
comprised of online adjunct and full-time faculty who instruct undergraduate, graduate, or doctoral level online courses from two public universities and one private university in the Southwest of the United States. The online faculty population targeted in this study totals 4,705 individuals: 941 teaching at a Public 1 university, 764 at a Public 2 university, and 3000 at the private university. The researcher conducted this research with a nonrandom sample of volunteer respondents.

\section{Procedure}

The preliminary analysis involved assessing the data quality in terms of completeness (whether each participant answered all questions) and accuracy (whether the numeric scores were within the 5-point range). This was accomplished by computing frequencies for all variables to identify missing data and check the score range. The first section of the analysis involved computing and presenting descriptive information about the sample. The researcher ran appropriate frequencies for all items included in the demographic questionnaire.

\section{Materials and Measures}

The researcher collected primary data through an online survey. A survey was a systematic way to collect data (Groves et al., 2009). The survey instrument for data collection included 55 questions grouped into two sections. Eleven demographic questions designed by this researcher were needed to collect information about the respondents' gender, age, highest degree earned, type of institution where they teach online courses, employment status (adjunct versus. full time), years teaching in higher education institutions, and years teaching in online higher education institutions. The variables included online faculty's knowledge about the indicators of brain-based learning, beliefs about brain-based learning, and indicators of brainbased learning practices.

\section{Descriptive Statistics}

Descriptive statistics were computed to provide a picture of the sample and to answer the first research question. The analysis needed to answer the second and third research questions involved the computation of three dependent variables. The aggregation of questionnaire items involved the computation of mean values for the groups of items: faculty knowledge of brain-based learning theory
(BBLT), beliefs about BBLT, and BBLT practices.

\section{Descriptive Data}

The participants in this study were online adjunct and full-time faculty from two public universities and one private university in the Southwest region of the United States. The first goal of this study was to collect online faculty demographics. Eleven items of demographic information were collected (i.e., public or private university, adjunct or fulltime, gender, age, years teaching online and in higher education institutions, and degree earned). Table 1 summarizes the characteristics of the online adjunct and full-time faculty identifying the 11 pieces of demographic data based on years of teaching in higher education and the knowledge, beliefs, and practices of brain-based learning techniques.

Table 1. Descriptive Demographic Statistics

\begin{tabular}{llccc}
\hline & & \multicolumn{3}{c}{ Years Teaching } \\
& & N & M & SD \\
\cline { 2 - 5 } Public or Private University & Public & 118 & 10.73 & 8.62 \\
\cline { 2 - 5 } & Private & 180 & 8.61 & 10.96 \\
\hline \multirow{2}{*}{ Part-time or Full-time Status } & Full Time & 118 & 8.29 & 6.87 \\
\cline { 2 - 5 } & Part Time & 180 & 10.21 & 11.75 \\
\hline \multirow{2}{*}{ Gender } & Male & 113 & 10.94 & 13.27 \\
\cline { 2 - 5 } & Female & 185 & 8.54 & 7.51 \\
\hline \multirow{4}{*}{ Age Group } & $20-29$ & 5 & 2.60 & 1.14 \\
\cline { 2 - 5 } & $30-39$ & 67 & 4.63 & 3.24 \\
\cline { 2 - 5 } & $40-49$ & 84 & 8.21 & 4.85 \\
\cline { 2 - 5 } & $50-59$ & 79 & 9.89 & 7.80 \\
\cline { 2 - 5 } & $60-69$ & 57 & 15.95 & 17.53 \\
\cline { 2 - 5 } & $70-79$ & 6 & 19.00 & 14.17 \\
\hline \multirow{2}{*}{ Degree Earned } & Master's & 169 & 7.98 & 10.83 \\
\cline { 2 - 5 } & PhD/EdD & 129 & 11.38 & 8.81 \\
\hline
\end{tabular}

The present study's variables included the online faculty's usage of brain-based learning as an academic practice based on faculty hiring status (adjunct versus full-time faculty) and type of institution (private university versus public university). The first section of the questionnaire involved descriptive data on the dependent variables, demographics, and faculty status. The descriptive analysis was performed for the whole sample and then by independent variables. No hypothesis was needed. As shown in Table 2, 118 
online full-time faculty and 180 online adjunct faculty from two public universities and one private university participated. The participants responded to the questions regarding knowledge of BBLT, beliefs of BBLT, and practices of BBLT. Based on the descriptive data in Table 3 , online faculty members utilized brain-based learning techniques as an academic practice in the online asynchronous higher education environment.

Table 2. Participants by Type of Institution and Faculty Status

\begin{tabular}{lllccc}
\hline $\begin{array}{l}\text { Independent } \\
\text { Variables }\end{array}$ & Groups & Frequency & Percent & $\begin{array}{c}\text { Valid } \\
\text { Percent }\end{array}$ & $\begin{array}{c}\text { Cumulative } \\
\text { Percent }\end{array}$ \\
\hline \multirow{2}{*}{$\begin{array}{l}\text { Type of } \\
\text { Institution }\end{array}$} & Public & 118 & 39.6 & 39.6 & 39.6 \\
\cline { 2 - 6 } & Private & 180 & 60.4 & 60.4 & 100.0 \\
\cline { 2 - 6 } & Total & 298 & 100.0 & 100.0 & \\
\hline \multirow{2}{*}{$\begin{array}{l}\text { Faculty } \\
\text { Status }\end{array}$} & Full Time & 118 & 39.6 & 39.6 & 39.6 \\
\cline { 2 - 6 } & Part Time & 180 & 60.4 & 60.4 & 100.0 \\
\cline { 2 - 6 } & Total & 298 & 100.0 & 100.0 & \\
\hline
\end{tabular}

However, there appeared to be a lack of knowledge of brain-based learning techniques for both adjunct and full-time faculty, thereby supporting the need for training and professional development. The descriptive analysis indicated that there was an overall mean score of $\mathrm{M}=3.43$ and $\mathrm{SD}=.51$ between the online full-time faculty and online adjunct faculty from the public university's knowledge of brain-based learning, as well as an overall mean score of $\mathrm{M}=3.31$ and $\mathrm{SD}=.49$ between online full-time faculty and online adjunct faculty from the private university's knowledge of brain-based learning (Table 4).

\section{Data Analysis}

After combining the responses, the data were imported into SPSS where further manipulation occurred. Outliers were checked for, as well as straight-liners (people who answered the same all the way down). This study had neither outliers nor straight-liners. Also, any scores in which a person did not answer were replaced with the mean score for that question. For research question one, descriptive statistics were performed on the dependent variables. Further, the research tested for internal reliability by computing Cronbach's alpha. The researcher computed and aggregated the question items on each scale to compute the three dependent variables and answer the first research question. Reliability analysis was conducted to determine internal reliability of the survey administered. Table 3 presents the overall scale as well as the three subscales of knowledge, beliefs, and practices, which are included in a separate analysis.

Table 3. Reliability Statistics

\begin{tabular}{|c|c|}
\hline Scale & A \\
\hline Overall & 0.845 \\
\hline Knowledge & 0.751 \\
\hline Beliefs & 0.565 \\
\hline Practices & 0.569 \\
\hline
\end{tabular}

The second section of the brain-based learning survey consisted of 36 items that were categorized into three different scales:

1. knowledge of BBLT (14 questions);

2. beliefs of BBLT (13 questions); and

3. practices of BBLT (nine questions).

The participants were asked to answer the survey questions using a five-point ordinal scale and five-point equal-interval scale, which included the following responses: strongly disagree to strongly agree and never, half the time, to always. Overall, the scale produced good internal reliability at 0.845 . However, the subscales ranged from poor to good at 0.565 to 0.751 . A lower level of alpha tends to show a decrease in the power of a study, thereby making it impossible to detect true differences, which could be a limitation when trying to detect a significant effect in beliefs.

The MANOVA was appropriate with the $2 \times 2$ factorial design to test the hypotheses associated with research questions two and three. A nonrandom sample of 80 participants from three of the four groups was used to create an equal sample size for each group. The only group that did not have 80 participants was the online full-time faculty from a public university. There was a limitation in the process of collecting data in the fourth cell. It appears there are enough full-time faculty members at a public university teaching online course, but the researcher could not obtain sufficient responses from them. The two public research institutions in this study use online programs as a supplement to their larger campus initiatives rooted in a traditional brick-and-mortar setting. The private university 
uses the online platform as a primary modality employing over 3,000 online faculty members. A majority of deans at the public universities refused to send the survey to the online faculty. Each question was then analyzed to ensure valid scores for each question. Any question that did not hold a valid response was recoded as missing. For any participant who marked two answers to one question, that response was deemed invalid. The missing values were substituted by the mean values. The subscales were calculated by finding the overall mean for the subscale questions. The level of statistical significance adopted for this study was alpha $=.05$.

\section{RESULTS}

The first research question framed the research needed to accomplish the first goal of this study, specifically the demographics of online faculty and usage of BBLT as an academic practice. In response to Research Question 1, the descriptive data analysis showed that the faculty from the public universities scored slightly but consistently higher than those from the private university in terms of all three measures of utilization of brainbased learning techniques in the online higher education environment (Table 4). In terms of BBLT knowledge, the public university faculty showed a mean of 3.43 as compared to the 3.31 mean of the faculty from the private university (difference of 0.12 points). In terms of BBLT beliefs, the public university faculty showed a mean of 3.52 as compared to the 3.48 mean of the faculty from the private university (difference of 0.04 points). The

Table 4. Descriptive Statistics for the Dependent

Variables by Type of Institution and Faculty Status

\begin{tabular}{|c|c|c|c|c|c|c|c|}
\hline & & \multicolumn{2}{|c|}{ Knowledge } & \multicolumn{2}{|c|}{ Beliefs } & \multicolumn{2}{|c|}{ Practices } \\
\hline & & M & SD & M & SD & $\mathrm{M}$ & SD \\
\hline \multirow[t]{3}{*}{ Public } & Full Time & 3.46 & .49 & 3.52 & .38 & 3.47 & .42 \\
\hline & Part Time & 3.42 & .51 & 3.52 & .31 & 3.44 & .46 \\
\hline & Total & 3.43 & .51 & 3.52 & .33 & 3.45 & .44 \\
\hline \multirow[t]{3}{*}{ Private } & Full Time & 3.25 & .48 & 3.45 & .36 & 3.22 & .43 \\
\hline & Part Time & 3.38 & .50 & 3.51 & .30 & 3.35 & .43 \\
\hline & Total & 3.31 & .49 & 3.48 & .33 & 3.29 & .44 \\
\hline \multirow[t]{3}{*}{ Whole Sample } & Full Time & 3.30 & .49 & 3.47 & .36 & 3.28 & .44 \\
\hline & Part Time & 3.40 & .51 & 3.52 & .30 & 3.40 & .44 \\
\hline & Total & 3.36 & .50 & 3.50 & .33 & 3.35 & .45 \\
\hline
\end{tabular}

largest difference was in terms of BBLT practices ( 0.16 points): The public university faculty showed a mean of 3.52 as compared to the 3.48 mean of the faculty from the private university.

Full-time faculty at the public university knowledge of brain-based learning techniques data analysis showed the mean score of 3.46 and the standard deviation of .49 . For the adjunct faculty at the public university knowledge of brain-based learning techniques data analysis showed the mean score of 3.42 and the standard deviation of .51. The full-time faculty at the private university knowledge of brain-based learning techniques data analysis showed the mean score of 3.25 and the standard deviation of .48. Adjunct faculty at the private university knowledge of brain-based learning techniques data analysis showed the mean score of 3.38 and the standard deviation of .50.

Table 5 presents the number of online faculty broken down by gender. The total sample size was 298. The results of the demographic statistics by gender showed 113 male and 185 female participants. Based on the male gender group, the descriptive analysis indicated that the score for males on knowledge was $(\mathrm{M}=3.27, \mathrm{SD}=.48)$ compared to females $(\mathrm{M}=3.42, \mathrm{SD}=.51)$. The score for males on beliefs was $(\mathrm{M}=3.44, \mathrm{SD}=.35)$ compared to females $(\mathrm{M}=3.53, \mathrm{SD}=.31)$. The score for males on practices was $(\mathrm{M}=3.26, \mathrm{SD}=.48)$ compared to females $(\mathrm{M}=3.40, \mathrm{SD}=.41)$.

Table 6 presents the demographic descriptor of age to ensure adequate distribution of data among age groups. Based on the results, of the 298 survey respondents, the age group 40-49 represented the highest response of 84 completed surveys, the

Table 5. Descriptive Statistics for the Dependent

Variables by Faculty Gender

\begin{tabular}{llccc}
\hline Gender & & Knowledge & Beliefs & Practices \\
\hline \multirow{4}{*}{ Male } & $\mathrm{n}$ & 113 & 113 & 113 \\
& $\mathrm{M}$ & 3.27 & 3.44 & 3.26 \\
& $\mathrm{SD}$ & 0.48 & 0.35 & 0.48 \\
\hline \multirow{4}{*}{ Female } & $\mathrm{n}$ & 185 & 185 & 185 \\
& $\mathrm{M}$ & 3.42 & 3.53 & 3.40 \\
& SD & 0.51 & 0.31 & 0.41 \\
\multirow{3}{*}{ Total } & $\mathrm{n}$ & 298 & 298 & 298 \\
& $\mathrm{M}$ & 3.36 & 3.50 & 3.35 \\
& SD & 0.50 & 0.33 & 0.45 \\
\hline
\end{tabular}


mean score of knowledge $(\mathrm{M}=3.33, \mathrm{SD}=.47)$, beliefs $(\mathrm{M}=3.51, \mathrm{SD}=.32)$ and practices $(\mathrm{M}=$ $3.36, \mathrm{SD}=.40$ ).

The demographic descriptor for highest degree earned was included to illustrate an adequate distribution of data among knowledge, belief, Table 6. Descriptive Statistics for the Dependent

Variables by Faculty Age Group

\begin{tabular}{|c|c|c|c|c|}
\hline Age Group & & Knowledge & Beliefs & Practices \\
\hline & $\mathrm{n}$ & 5 & 5 & 5 \\
\hline \multirow[t]{3}{*}{$20-29$} & M & 3.29 & 3.57 & 3.02 \\
\hline & SD & 0.41 & 0.28 & 0.47 \\
\hline & $\mathrm{n}$ & 67 & 67 & 67 \\
\hline \multirow[t]{3}{*}{$30-39$} & M & 3.31 & 3.48 & 3.31 \\
\hline & SD & 0.50 & 0.32 & 0.46 \\
\hline & $\mathrm{n}$ & 84 & 84 & 84 \\
\hline \multirow[t]{3}{*}{$40-49$} & M & 3.33 & 3.51 & 3.36 \\
\hline & SD & 0.47 & 0.32 & 0.40 \\
\hline & $\mathrm{n}$ & 79 & 79 & 79 \\
\hline \multirow[t]{3}{*}{$50-59$} & M & 3.40 & 3.47 & 3.36 \\
\hline & SD & 0.53 & 0.34 & 0.49 \\
\hline & $\mathrm{n}$ & 57 & 57 & 57 \\
\hline \multirow[t]{3}{*}{$60-69$} & M & 3.40 & 3.53 & 3.40 \\
\hline & SD & 0.53 & 0.35 & 0.45 \\
\hline & $\mathrm{n}$ & 6 & 6 & 6 \\
\hline \multirow[t]{3}{*}{$70-79$} & M & 3.49 & 3.47 & 3.39 \\
\hline & SD & 0.48 & 0.21 & 0.36 \\
\hline & $\mathrm{n}$ & 298 & 298 & 298 \\
\hline \multirow[t]{2}{*}{ Total } & M & 3.36 & 3.50 & 3.35 \\
\hline & SD & 0.50 & 0.33 & 0.45 \\
\hline
\end{tabular}

and practices of brain-based learning based on education level. The responses varied by master and doctoral level degrees. Table 7 shows the response of 169 online faculty who held a master's degree and 129 online faculty who held a $\mathrm{PhD} / \mathrm{EdD}$ degree. The descriptive analysis showed that for online faculty who held a master's degree the score on knowledge was $(\mathrm{M}=3.33, \mathrm{SD}=.49)$ compared to online faculty who held a $\mathrm{PhD} / \mathrm{EdD}$ degree $(\mathrm{M}$ $=3.40, \mathrm{SD}=.51)$. For online faculty who held a master's degree the score on belief was $(\mathrm{M}=3.48$, $\mathrm{SD}=.34)$ compared to online faculty who held a $\mathrm{PhD} / \mathrm{EdD}$ degree $(\mathrm{M}=3.51, \mathrm{SD}=.32)$. For online faculty who held a master's degree the score on practices was $(\mathrm{M}=3.28, \mathrm{SD}=.43)$ compared to online faculty who held a $\mathrm{PhD} / \mathrm{EdD}$ degree $(\mathrm{M}=$ $3.44, \mathrm{SD}=.45$ ).

Two additional research questions were needed to accomplish the second goal of this study. The researcher performed a $2 \times 2$ MANOVA (Table 8)

Table 7. Descriptive Statistics for the Dependent

Variables by Faculty Level of Education

\begin{tabular}{ccccc}
\hline Degree Earned & & Knowledge & Beliefs & Practices \\
\hline \multirow{3}{*}{ Master's } & $\mathrm{n}$ & 169 & 169 & 169 \\
& $\mathrm{M}$ & 3.33 & 3.48 & 3.28 \\
& $\mathrm{SD}$ & 0.49 & 0.34 & 0.43 \\
\hline \multirow{3}{*}{ PhD/EdD } & $\mathrm{n}$ & 129 & 129 & 129 \\
& $\mathrm{M}$ & 3.40 & 3.51 & 3.44 \\
& $\mathrm{SD}$ & 0.51 & 0.32 & 0.45 \\
\hline \multirow{3}{*}{ Total } & $\mathrm{n}$ & 298 & 298 & 298 \\
& $\mathrm{M}$ & 3.36 & 3.50 & 3.35 \\
& $\mathrm{SD}$ & 0.50 & 0.33 & 0.45 \\
\hline
\end{tabular}

to determine if there were any differences among the online faculty attributable to faculty status (adjunct versus full time), type of institution (public university versus private university), or to the interaction of these two variables in regard to the average BBLT scores on the three subscales.

Findings for research question 2. The MANOVA results presented in Table 8 showed no significant difference in the usage of brainbased learning techniques as an academic practice in the online asynchronous higher education environment attributable to faculty's hiring status (full time versus adjunct). There was no statistically significant main effect of the faculty hiring status (adjunct versus full time) on knowledge, beliefs, and practices. Based on these findings, the null hypothesis was accepted.

Findings for research question 3 . Based on the results in Table 8 , the only significant difference between online faculty from public universities compared to those from the private university was in terms of BBLT practices (means: 3.45 and 3.28, respectively). The main effect of type of institution on practices was statistically significant, $\mathrm{F}(1,294)$ $=1.62, \mathrm{p}=.004, \mathrm{n} 2=.028$. These findings provided partial support for the alternative hypothesis stated for the third research question. Consequently, the null hypothesis was rejected for research question three. The MANOVA results showed no statistically significant interactive effect of type of institution 
Table 8. Tests of Between-Subjects Effects

\begin{tabular}{|c|c|c|c|c|c|c|c|}
\hline Source & $\begin{array}{c}\text { Dependent } \\
\text { Variable }\end{array}$ & $\begin{array}{l}\text { Type III Sum of } \\
\text { Squares }\end{array}$ & df & Mean Square & $F$ & Sig. & $\begin{array}{c}\text { Partial Eta } \\
\text { Squared }\end{array}$ \\
\hline \multirow{3}{*}{ Corrected Model } & Knowledge & $1.834 a$ & 3 & .611 & 2.485 & .061 & .025 \\
\hline & Beliefs & $.275 b$ & 3 & .092 & .851 & .467 & .009 \\
\hline & Practices & $2.604 c$ & 3 & .868 & 4.535 & .004 & .044 \\
\hline \multirow{3}{*}{ Intercept } & Knowledge & 2644.094 & 1 & 2644.094 & 10746.306 & .000 & .973 \\
\hline & Beliefs & 2840.832 & 1 & 2840.832 & 26350.010 & .000 & .989 \\
\hline & Practices & 2630.731 & 1 & 2630.731 & 13742.670 & .000 & .979 \\
\hline \multirow{3}{*}{$\begin{array}{c}\text { Type of } \\
\text { Institution }\end{array}$} & Knowledge & .923 & 1 & .923 & 3.753 & .054 & .013 \\
\hline & Beliefs & .114 & 1 & .114 & 1.061 & .304 & .004 \\
\hline & Practices & 1.616 & 1 & 1.616 & 8.444 & .004 & .028 \\
\hline \multirow{3}{*}{ Hiring Status } & Knowledge & .139 & 1 & .139 & .566 & .452 & .002 \\
\hline & Beliefs & .043 & 1 & .043 & .403 & .526 & .001 \\
\hline & Practices & .159 & 1 & .159 & .830 & .363 & .003 \\
\hline \multirow{3}{*}{$\begin{array}{c}\text { Type of } \\
\text { Institution times } \\
\text { Hiring Status }\end{array}$} & Knowledge & .446 & 1 & .446 & 1.812 & .179 & .006 \\
\hline & Beliefs & .043 & 1 & .043 & .397 & .529 & .001 \\
\hline & Practices & .344 & 1 & .344 & 1.799 & .181 & .006 \\
\hline \multirow{3}{*}{ Error } & Knowledge & 72.338 & 294 & .246 & & & \\
\hline & Beliefs & 31.697 & 294 & .108 & & & \\
\hline & Practices & 56.280 & 294 & .191 & & & \\
\hline \multirow{3}{*}{ Total } & Knowledge & 3440.054 & 298 & & & & \\
\hline & Beliefs & 3675.724 & 298 & & & & \\
\hline & Practices & 3402.090 & 298 & & & & \\
\hline \multirow{3}{*}{ Corrected Total } & Knowledge & 74.172 & 297 & & & & \\
\hline & Beliefs & 31.972 & 297 & & & & \\
\hline & Practices & 58.884 & 297 & & & & \\
\hline
\end{tabular}

a. R Squared $=.025$ (Adjusted R Squared $=.015$ )

b. RSquared $=.009$ (Adjusted R Squared $=-.002$ )

c. R Squared $=.044$ (Adjusted R Squared $=.034)$

and faculty hiring status.

\section{LIMITATIONS}

There were a few limitations inherent to the definition of BBLT, the scope of the study, the instrument, and the data collection process. These limitations were related to the investigation of online faculty's knowledge and beliefs about brainbased learning and their usage of brain-based learning in an online classroom. The limitations were as follows:

1. Random sampling was not possible; data collection was from a nonrandom sample of voluntary participants. In a study like this one, volunteers are often more interested in the research topic than the target population. Consequently, based on the nonrandom sample of voluntary participants, that undercut the external validity of this study.

2. It was challenging to obtain sufficient participants to meet the requirements of the $2 \times 2$ factorial design. Consequently, the three-week data collection period did not need to be extended in order to capture a greater number of responses.

\section{FUTURE RECOMMENDATIONS}

Overall, this study found that there was no significant difference in the usage of brain-based learning techniques as an academic practice in the online asynchronous higher education environment attributed to faculty's hiring status: full time versus adjunct. The study further found that there 
was a significant difference between the online faculty at the public universities and the online faculty at the private university related to their practices with brain-based learning techniques. The recommendations relate to the significance in the framework of studying brain-based learning techniques in an online asynchronous higher education environment. If online faculty actually utilized BBLT in an online learning environment, what might be the results? More research might provide insight to other academic practices that can be utilized in an online learning environment. Would students whose online postsecondary instructors incorporate BBLT in the online classroom show more engagement and meaningful learning in all content areas? Might there be an increase in selfconfidence and positive communication? Would students be less stressed and have less anxiety? More research in these areas could provide the answer. Future qualitative research could be conducted in this study to determine the perceptions of other factors that contributed to usage of BBLT in the online higher education environment. This raises the question as to whether students and faculty feel utilizing BBLT in the online classroom enhances teacher-student engagement.

\section{SUMMARY}

Supporting and implementing professional development and training focused on brain-based learning techniques can help with online faculty members' academic practices. Using brain-based learning techniques is one way to keep students' discussions on topic and to ensure conversations are interesting and content based. Much has been written recently on participation in asynchronous discussions, including the effects of participation levels on learning outcomes, the relationship among participation levels, student satisfaction within the online classroom, and factors affecting participation levels (Watson, 2008). Improving communication and academic practices in the online learning environment has become an increasingly common area of research as scholars seek to uncover how interaction best improves student learning. Online faculty who provide good stress environments are more likely to enhance learning within students by helping them to solve problems, increase their motivation, and strengthen their critical thinking skills (Jensen, 2008). Online faculty who participate in professional development or training on brain-based learning techniques will engage students in meaningful learning by keeping students active in the discussion forums. 


\section{REFERENCES}

Abel, R. (2005). Implementing best practices in online learning. Educause Quarterly. (3), 75-77.

Akyürek, E., \& Afacan, Ö. (2013). Effects of brain-based learning approach on students' motivation and attitudes levels in science class. Mevlana International Journal, 3(1), 104-199.

Berg, Z., \& Haung, Y. (2004). A model for sustainable student retention: A holistic perspective on the student dropout problem with special attention to e-learning. DEOSNEWS, 13(5). doi:10.1.1.129.1495

Braidic, S. (2009). Fostering successful learning communities to meet the diverse needs of university students by creating brain-based online learning environments. International Journal of Information and Communication Technology Education, 5(4). 18-25. doi:10.4018/jicte.2009041002

Burton, E. (2009). 21st century focus: Brain-based learning education students as a whole and teaching the way the brain naturally learns best. Seen Magazine. Retrieved from http:// www.seenmagazine.us/articles/article-detail/articleid/47/21sup-st-sup-century-focus-brain-based-learning.aspx

Freeman, G., \& Wash, P. (2013). You can lead students to the classroom, and you can make them think: Ten brain-based strategies for college teaching and learning success. Journal on Excellence in College Teaching, 24(3), 99-120.

Gautreau, C. (2011). Motivational factors affecting the integration of a learning management system by faculty. Journal of Educators Online, 8(1).

Gregory, G., \& Chapman, C. (2002). Differentiated instructional strategies: One size doesn't fit all. Thousand Oaks, CA: Corwin Press.

Groves, R., Fowler, F., Couper, M., Lepkowski, J., Singer, E., \& Tourangeau, R. (2009). Survey methodology. Hoboken, NJ: Wiley \& Sons, Inc.

Hart, L. (1983). Human brain and human learning. White Plains, NY: Longman, Inc.

Jensen, E. (2008). Brain-based learning: The new paradigm of teaching (2nd ed.). Thousand Oaks, CA: Corwin Press.

Jensen, E. (2011). Brain-based education in action. Educational Horizons, 90(2), 5-6. doi:10.1177/0013175X1109000202

Kanter, M. (2013). Department launches college affordability and value outreach initiative today: Starting with student advocates [Web log post]. Home Room: The official blog of the U.S. Department of Education. Retrieved from https://blog.ed.gov/2013/09/department-launches-college- affordability-and-value-outreach-initiative-today-starting-withstudent-advocates/

Klinek, S. (2009). Brain-based learning: Knowledge, beliefs, and practices of College of Education faculty in the Pennsylvania state system of higher education (Doctoral Dissertation, Indiana University of Pennsylvania). Retrieved from https://knowledge.library.iup.edu/cgi/viewcontent. cgi?article=1909\&context $=$ etd

Mundy, M., Kupczynski, L., Ellis, J., \& Salgado, R. (2011). Setting the standard for faculty professional development in higher education. Journal of Academic \& Business Ethics. Retrieved from https://www.aabri.com/manuscripts/111041.pdf

Ozden, M., \& Gultekin, M. (2008). The effects of brain-based learning on academic achievement and retention of knowledge in science course. Electronic Journal of Science Education, 12(1), 1-17.

Raj, R. (2011). Evaluating the innovation of online learning systems in higher education. International Journal of Management Cases, 12, 12-23. doi:10.5848/APBJ.2011.00106.

Roman, T., Kelsey, K., \& Lin, H. (2010). Enhancing online education through instructor skill development in higher education. Online Journal of Distance Learning Administration, 13(4). Retrieved from https://www.learntechlib. org/p/52604/

Sloan Consortium. (2014). Babson study: Over 7.1 million higher ed students learning online. Babson Park, MA: Babson Survey Research Group. Retrieved from https://www.babson. edu/about/news-events/babson-announcements/babsonsurvey-study-of-online-learning/

Sullivan, W., \& Rosin, M. (2008). A new agenda for higher education: Shaping a life of the mind for practice. San Francisco, CA: Jossey-Bass.

Varvel, V. E. (2007). Master online teacher competencies. Online Journal of Distance Learning Administration, 10(1). Retrieved from https://www.westga.edu/ distance/ojdla/spring101/ varvel101.htm

Watson, A. (2008). Developing teaching practices for more effective use of asynchronous discussion: A preliminary investigation. In Proceedings ascilite Melbourne 2008 (pp. 1090-1099). 